\title{
sciendo
}

\section{Organic pollutant removal from marine diesel engine off-gases under electron beam and hybrid electron beam and wet scrubbing process}

\author{
Yongxia Sun $\mathbb{1}$, \\ Andrzej G. Chmielewski $\mathbb{1}^{\circ}$, \\ Andrzej Pawelec, \\ Gösta Mattausch, \\ Toms Torims
}

\begin{abstract}
The removal of organic pollutants from ship emission was studied using two processes namely electron beam (EB) and hybrid EB with wet scrubbing process. A mobile accelerator unit was used to treat $4915 \mathrm{Nm}^{3} / \mathrm{h}$ of flue gas emitted from a tugboat in Riga Shipyard. A volume of $3 \mathrm{~m}^{3}$ seawater containing $36.8 \mathrm{mM}$ of $\mathrm{NaClO}_{2}$ oxidant was used as a wet scrubber solution. Organic pollutants, mainly volatile organic pollutants (VOCs), were collected at three different sampling points, before and after irradiation vessels, and after wet-scrubber unit, respectively. They were collected with glass sampling bottles, tedlar bags, Coconut Shell Charcoal (CSC) sorbents and XAD-2 sorbents. $\mathrm{CH}_{3} \mathrm{OH}$ and $\mathrm{CH}_{3} \mathrm{OH} / \mathrm{CH}_{2} \mathrm{Cl}_{2}$ (1:1) were used to extract VOCs from CSC and XAD-2 sorbents, respectively. Syringe filters were used to obtain the solid-free extraction solutions. They were concentrated using a micro-extractor under continuously blowing high-purity Ar. A gas chromatography-mass spectrometry (GC-MS) was used for analysis. The identified organic compounds were: aliphatic hydrocarbons (dodecane $\mathrm{C}_{12} \mathrm{H}_{26}$ to eicosane $\mathrm{C}_{20} \mathrm{H}_{42}$ ), aromatic hydrocarbon (toluene), esters $\left(\mathrm{C}_{3} \mathrm{H}_{7} \mathrm{COOCH}_{3},\left(\mathrm{C}_{4} \mathrm{H}_{9} \mathrm{OCO}\right)_{2} \mathrm{C}_{6} \mathrm{H}_{4}\right)$, nitro compounds $\left(\mathrm{C}_{3} \mathrm{H}_{5} \mathrm{NO}_{3}, \mathrm{C}_{4} \mathrm{H}_{7} \mathrm{NO}_{2}\right)$ and acid $\left(\mathrm{C}_{7} \mathrm{H}_{15} \mathrm{COOH}\right)$. After $4.2 \mathrm{kGy}$ EB irradiation, around $50-100 \%$ aliphatic hydrocarbons, $83 \%$ toluene and $7.5 \%\left(\mathrm{C}_{4} \mathrm{H}_{9} \mathrm{OCO}\right)_{2} \mathrm{C}_{6} \mathrm{H}_{4}$ were removed from the off-gases, and after EB hybrid wet-scrubber process, most organic compounds including nitro compounds were removed. Only trace amount of toluene, hexadecane, octadecane and dibutyl phthalate were found to be present in the gas phase.
\end{abstract}

Keywords: Electron beam $\bullet$ Marine diesel engine $\bullet$ Off-gases $\bullet$ Organic pollutants $\bullet$ VOC $\bullet$ Wet scrubber

Y. Sun ${ }^{\bowtie}$, A. G. Chmielewski, A. Pawelec

Institute of Nuclear Chemistry and Technology

Dorodna 16 Str., 03-195 Warsaw, Poland

E-mail: y.sun@ichtj.waw.pl

G. Mattausch

Fraunhofer Institute for Organic Electronics, Electron

Beam and Plasma Technology, FEP

Dresden, Germany

T. Torims

Riga Technical University, Riga, Latvia

Received: 28 October 2020

Accepted: 14 December 2020

\section{Introduction}

Combinations of $\mathrm{SO}_{2}, \mathrm{NO}_{\mathrm{x}}$ and volatile organic pollutants (VOCs) emitted from marine diesel engine off-gases cause serious problem to the environment and human health. Some VOCs are ozone-depleting substances in stratosphere, ozone formation in troposphere and precursor for secondary aerosol formation. Some VOCs have direct adverse effect on human health. According to US Environmental Protection Agency (USEPA) Clean Air Act, 187 hazardous air pollutants were listed [1] that also included toluene. The strict regulation concerning $\mathrm{SO}_{2}$ and $\mathrm{NO}_{\mathrm{x}}$ emission from ship emission has been enacted accordingly. Based on MARPOL air pollution Annex VI, sulphur emission from ship exhaust gas is not permitted to exceed $0.1 \%$ (wt/wt) sulphur content in sulphur emission control areas (SECA); $0.5 \%$ sulphur content is the maximum limit in global marine area. Limits of $\mathrm{NO}_{\mathrm{x}}$ emission has been put into force in North America since June 20, 2019 and the values range between $3.4 \mathrm{~g} / \mathrm{kWh}$ and $2 \mathrm{~g} / \mathrm{kWh}$ depending on the engine speed and based on TIER III requirement [2].

0029-5922 @ 2021 The Author(s). Published by the Institute of Nuclear Chemistry and Technology.

This is an open access article under the CC BY-NC-ND 4.0 licence (http://creativecommons.org/licences/by-nc-nd/4.0/). 


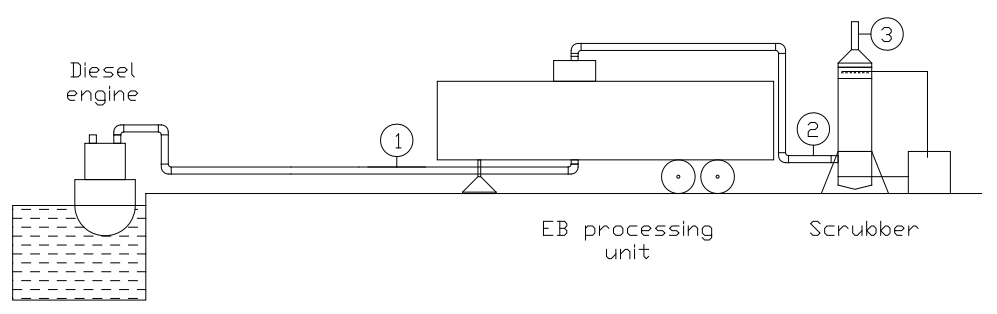

Fig. 1. The sampling points of the organic pollutants.

Heavy fuel oil (HFO), due to its low cost, is a main energy source for marine industry. However, high concentrations of $\mathrm{SO}_{2}$ and $\mathrm{NO}_{\mathrm{x}}$ are emitted during combustion of HFO, and organic pollutants are also generated. To reduce $\mathrm{SO}_{2}$ emission, wet scrubbing method is generally used to scavenge $\mathrm{SO}_{2}$ from off-gases emitted from the ship engines and boilers. To reduce $\mathrm{NO}_{\mathrm{x}}$ emission, catalyst reduction method is mainly applied [3]. A process of electron beam (EB) hybrid with wet-scrubbing is used to remove $\mathrm{SO}_{2}$ and $\mathrm{NO}_{\mathrm{x}}$ simultaneously from marine engine off-gases. The whole process was initially studied in the laboratory scale in the Institute of Nuclear Chemistry and Technology (INCT) [4], and then tested in a real maritime environment in Riga Shipyard within the ARIES proof-of-concept project. It was the first pilot test plant in the world and in the real maritime conditions. This pilot plant set-up and results of $\mathrm{SO}_{2}$ and $\mathrm{NO}_{\mathrm{x}}$ removal have been described in detail [5]. During the pilot test for the removal of $\mathrm{SO}_{2}$ and $\mathrm{NO}_{\mathrm{x}}$ from ship emission, organic pollutants before and after treatment were sampled and collected. They were transported to INCT laboratory for analysis. Subsequently organic pollutant removal under EB and EB hybrid wet-scrubbing process was studied. This paper contains the initial test results for the removal of organic pollutants.

\section{Experimental set-up and analysis of the samples}

\section{Organic pollutant sampling system}

Flue gas was generated from a tugboat 'Orkāns' equipped with two two-stroke diesel engines in Riga Shipyard. Sulphur-free fuel was used. Flue gas compositions were measured in three main points: at the inlet of the irradiation unit, at the outlet after irradiation unit and at the outlet of the plant after wet-scrubbing treatment. Two different types of flue gas analysers were used: Kane Quintox flue gas analyser (Kane Int. Limited, UK) at the inlet and outlet of the treatment plant and Land Lancom series II portable gas analyser (AMETEK Land, UK) after the irradiation unit. Concentration of the following elements of gas composition were determined by flue gas analysers: sulphur dioxide $\left(\mathrm{SO}_{2}\right)$, nitrogen monoxide (NO), nitrogen dioxide $\left(\mathrm{NO}_{2}\right)$, oxygen $\left(\mathrm{O}_{2}\right)$, carbon dioxide $\left(\mathrm{CO}_{2}\right)$, carbon monoxide $(\mathrm{CO})$ and hydrocarbons (CxHy). The temperature-values of flue gas before irradiation, after irradiation and after wet-scrubbing treatment were $133^{\circ} \mathrm{C}, 85^{\circ} \mathrm{C}$ and $34^{\circ} \mathrm{C}$, respectively. It was measured by using thermocouples type $\mathrm{K}$ manufactured by Czaki (Poland). Flue gas velocity was measured by Testo 452 anemometer produced by Testo, Germany. Flue gas of $4915 \mathrm{Nm}^{3} / \mathrm{h}$ emitted from tugboat 'Orkāns' was treated by deploying a mobile accelerator unit WESENITZ-II [5]. Also, $3 \mathrm{~m}^{3}$ seawater containing $3.3 \mathrm{~g} / \mathrm{dm}^{3} \mathrm{NaClO}_{2}$ oxidant was used as a wet scrubber solution. Temperature of the scrubbing solution increased from $27^{\circ} \mathrm{C}$ to $29^{\circ} \mathrm{C}$ after scrubbing flue gas. Organic pollutants' removal from ship emissions have been studied under two processes, EB and EB hybrid wet scrubbing process. The residence time of flue gas in the irradiation zone and the wet-scrubber were $0.112 \mathrm{~s}$ and $2.2 \mathrm{~s}$, respectively. Gaseous organic pollutants, mainly VOCs, were collected at three different sampling points: before irradiation vessel, after irradiation vessels and after wet-scrubber unit (Fig. 1). They were collected with glass sampling bottles, tedlar bags, Coconut Shell Charcoal (CSC) sorbents (SKC Inc., USA) and XAD-2 sorbents (SKC Inc., USA) according to USEPA Method 18 [6], and a scheme of the sampling system is presented in Fig. 2.

\section{Methodology of the analysis}

Fuel and combustion condition are the two main factors that influence the flue gas composition. In this pilot test, composition of flue gas emitted from diesel engine consists of $\mathrm{SO}_{2}, \mathrm{NO}_{\mathrm{x}}, \mathrm{CO}, \mathrm{CO}_{2}$, particulate matter (PM), hydrocarbons etc., and this composition is similar to the composition of flue gas emitted from heavy fuel combustion [7]. $\mathrm{SO}_{2}$, $\mathrm{NO}_{\mathrm{x}}, \mathrm{CO}, \mathrm{CO}_{2}, \mathrm{O}_{2}$ and total hydrocarbons were directly measured with portable flue gas analysers. For gaseous organic pollutants, glass sampling bottles and tedlar bags were used to collect very volatile compounds having high concentration. Further, adsorbents were used to concentrate the sample for the low concentration compounds, thus lowering the detection limit of these compounds [6]. A GCMS-QP5050 (Shimadzu company, Japan) analyser was used for analysis. Standard solutions, such as AK-102.0-NAS-10X standard, M-502-REG and AK-101AA-ARO standard were used for making calibration curves. All these standard solutions were ordered from AccuStandard company, USA. For the off-gases sampled using Tedlar bags and glass bottles, 500 microliter sampling gas was directly injected into the GC-MS analyser. For the off-gases adsorbed by the sorbents, $10 \mathrm{ml} \mathrm{CH}_{3} \mathrm{OH}$ (HPLC purity) and $\mathrm{CH}_{3} \mathrm{OH} / \mathrm{CH}_{2} \mathrm{Cl}_{2}$ (1:1, HPLC purity) were used to extract VOCs from CSC and XAD-2 sorbents, 

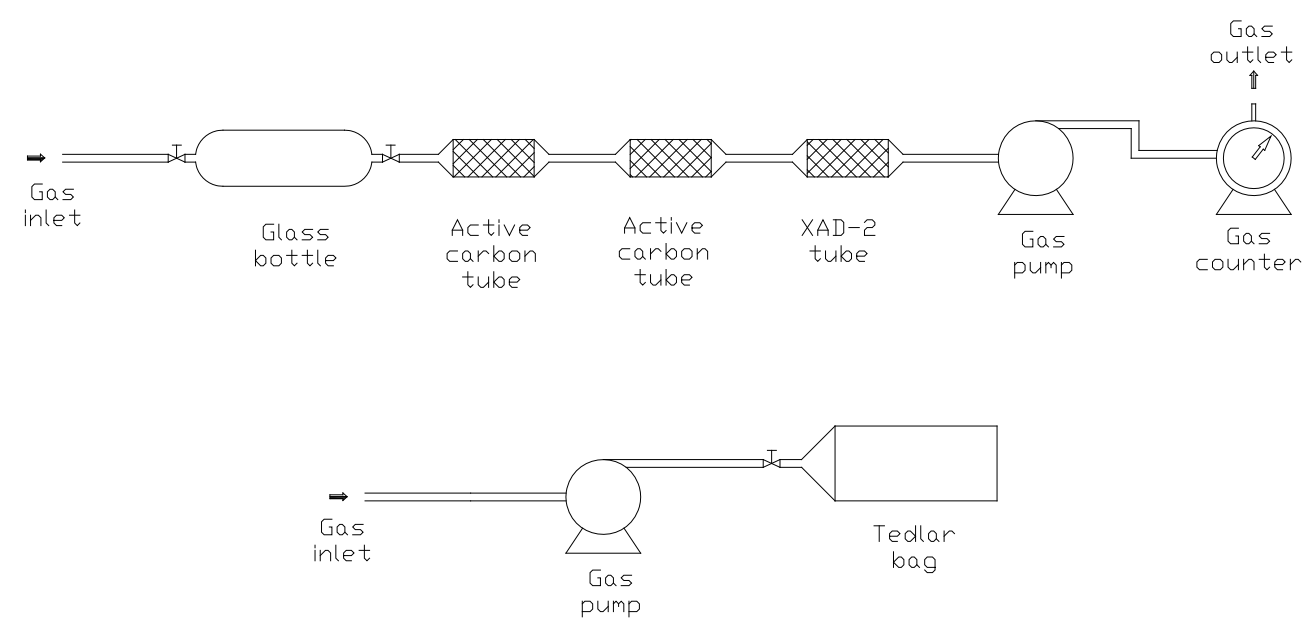

Fig. 2. A scheme of the sampling system.

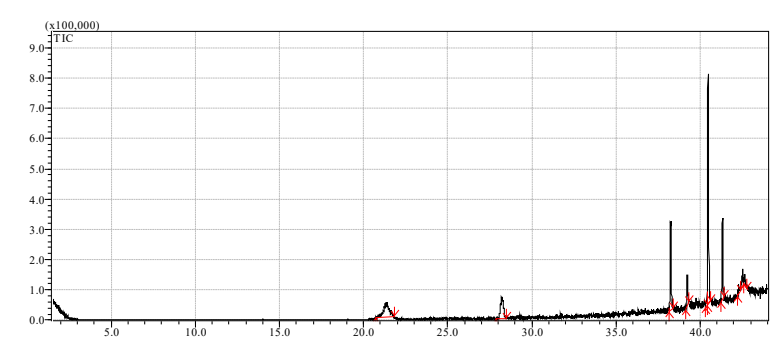

Fig. 3. A GC-MS spectrum of the flue gas before irradiation.

respectively. The solid-free extraction solutions were obtained by using syringe filters to separate extraction solution from sorbents. They were concentrated to $0.2 \mathrm{ml}$ using a micro-extractor under continuously blowing high-purity Ar (Argon-X5OS PRM, air products, Poland). Then, $1 \mu$ l concentrated solution was injected into the GC-MS for analysis. HP-5MS column $(30 \mathrm{~m} \times 0.25 \mathrm{~mm}$ ID $\times 25 \mu \mathrm{m}$, Agilent J\&W, USA) was used. The analytical conditions of GC-MS were as follows: $40^{\circ} \mathrm{C}$ held for $1 \mathrm{~min}$, increased to $60^{\circ} \mathrm{C}$ at $1^{\circ} \mathrm{C} / \mathrm{min}$, then increased to $280^{\circ} \mathrm{C}$ at $5^{\circ} \mathrm{C} / \mathrm{min}$, column flow was $1.2 \mathrm{ml} / \mathrm{min}$, split ratio was 100:1 when liquid sample was injected and the injection temperature was $250^{\circ} \mathrm{C}$ while the interface temperature was $280^{\circ} \mathrm{C}$; solvent cutting time was $2 \mathrm{~min}$. Electron ionization was applied and Wiley library was used for reference mass spectra.

\section{Results and discussion}

\section{Direct analysis of VOCs collected in glass bottle}

Off-gases (or flue gas) before and after treatment (EB or EB with scrubber) collected with glass sampling bottles and Tedlar bags were directly analysed. A GC-MS spectrum of off-gases before irradiation is shown in Fig. 3. Seven unidentified peaks (due to the lack of standards or database of reference mass spectra in the library) were recorded in the flue gas. After EB or EB was combined with the wet scrubber treatment, no peak was detected.

\section{Analysis of VOCs collected in the CSC sorbents}

CSC and XAD-2 sorbents were used to collect the flue gas samples before and after treatment. Quantities of $106 \mathrm{~L}, 68 \mathrm{~L}$ and $112 \mathrm{~L}$ of flue gas were sampled at the three different sampling points (before EB, after EB, after EB with scrubber), respectively. The results are presented in Fig. 4. Table 1 lists organic compounds, which were identified by the GC-MS analyser, eluting at different retention time (RT). Note that "+" in Table 1 means organic compounds detected by the GC-MS analyser; and "-" means organic compounds below detection limit. From
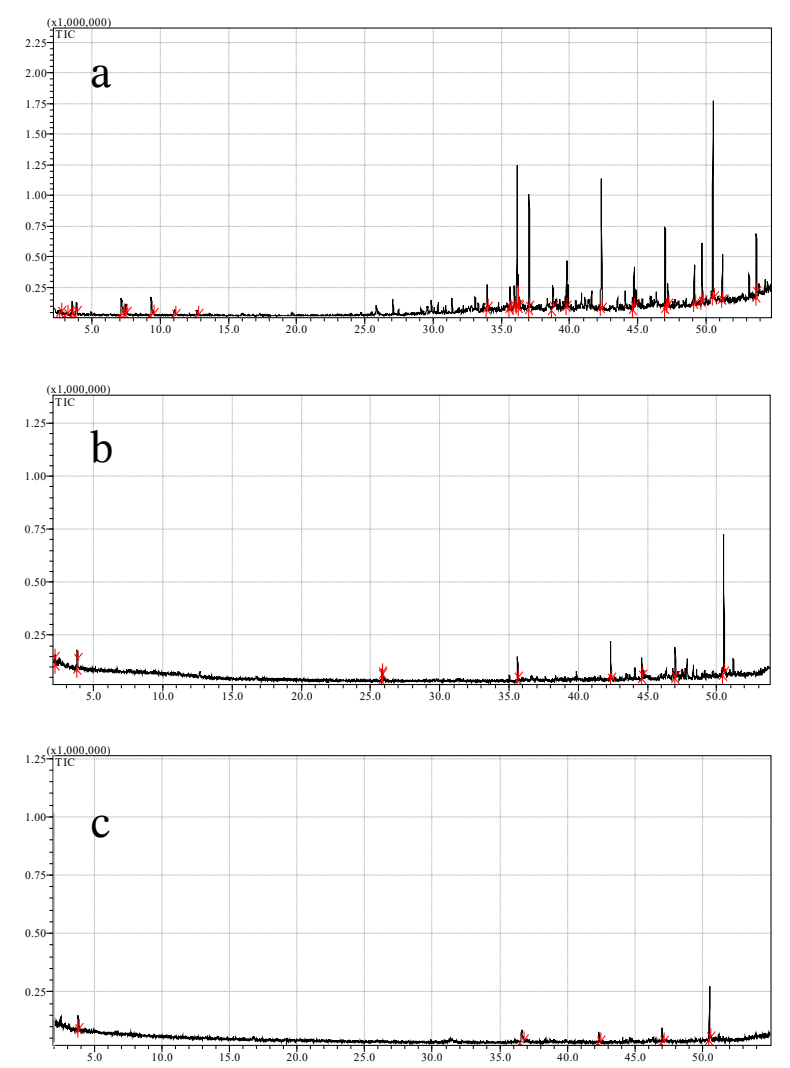

Fig. 4. (a) A GC-MS spectrum of flue gas collected with the CSC sorbents (a) before EB irradiation; (b) after EB irradiation; (c) after EB with wet scrubber treatment. 
Table 1. List of organic compounds eluting at different RT of the GC-MS spectrums presented in Fig. 4

\begin{tabular}{clccc}
\hline $\begin{array}{c}\text { RT } \\
(\mathrm{min})\end{array}$ & \multicolumn{1}{c}{ Compound } & $\begin{array}{c}\text { Ship } \\
\text { emission }\end{array}$ & $\begin{array}{c}\text { After } \\
\text { EB }\end{array}$ & $\begin{array}{c}\text { After EB } \\
\text { with wet scrubber }\end{array}$ \\
\hline 3.833 & Toluene & + & + & + \\
7.142 & Nitropropanone, $\mathrm{C}_{3} \mathrm{H}_{5} \mathrm{NO}_{3}, \mathrm{CH}_{3} \mathrm{COCH}_{2} \mathrm{NO}_{2}$ & + & - & - \\
7.442 & 1-Butene, 3-nitro-, $\mathrm{C}_{4} \mathrm{H}_{7} \mathrm{NO}_{2}, \mathrm{CH}_{2}=\mathrm{CHCH}_{2}\left(\mathrm{CH}_{3}\right) \mathrm{NO}_{2}$ & + & - & - \\
11.042 & Methyl butyrate, $\mathrm{C}_{5} \mathrm{H}_{10} \mathrm{O}_{2}, \mathrm{C}_{3} \mathrm{H}_{7} \mathrm{COOCH}_{3}$ & + & - & - \\
12.700 & Chlorotoluene, $\mathrm{C}_{7} \mathrm{H}_{7} \mathrm{Cl}$ & + & - & - \\
36.156 & Butoxyethoxyethyl acetate, $\mathrm{C}_{10} \mathrm{H}_{20} \mathrm{O}_{4}, \mathrm{CH}_{3} \mathrm{COO}\left(\mathrm{C}_{2} \mathrm{H}_{4} \mathrm{O}\right)_{2} \mathrm{C}_{4} \mathrm{H}_{9}$ & + & + & - \\
37.039 & Dodecane, $\mathrm{C}_{12} \mathrm{H}_{26}$ & + & + & - \\
39.798 & Pentadecane, $\mathrm{C}_{15} \mathrm{H}_{32}$ & + & - & + \\
42.351 & Hexadecane, $\mathrm{C}_{16} \mathrm{H}_{34}$ & + & + & - \\
44.739 & Heptadecane, $\mathrm{C}_{17} \mathrm{H}_{34}$ & + & - & + \\
47.004 & Octadecane, $\mathrm{C}_{18} \mathrm{H}_{38}$ & + & + & - \\
47.212 & Hexadecane, $2,6,10,14-$ tetramethyl-, $\mathrm{C}_{20} \mathrm{H}_{42}$ & + & - & - \\
49.152 & n-Eicosane, $\mathrm{C}_{20} \mathrm{H}_{42}$ & + & - & - \\
49.717 & Hexadecanoic acid, methyl ester, $\mathrm{C}_{17} \mathrm{H}_{34} \mathrm{O}_{2}$ & + & + \\
50.519 & Dibutyl phthalate, $\mathrm{C}_{16} \mathrm{H}_{22} \mathrm{O}_{4}, \mathrm{C}_{6} \mathrm{H}_{4}\left(\mathrm{COOC}_{4} \mathrm{H}_{9}\right)_{2}$ & + & - & - \\
51.208 & Heneicosane, $\mathrm{C}_{21} \mathrm{H}_{44}$ & + & + & - \\
53.701 & Octadecanoic acid, methyl ester, $\mathrm{C}_{19} \mathrm{H}_{38} \mathrm{O}_{2}$ & + & - & - \\
\hline
\end{tabular}

Table 2. List of the organic compounds eluting at different RT of the GC-MS spectrums presented in Fig. 5

\begin{tabular}{clccc}
\hline $\begin{array}{c}\text { RT } \\
(\mathrm{min})\end{array}$ & \multicolumn{1}{c}{ Compound name } & $\begin{array}{c}\text { Ship } \\
\text { emission }\end{array}$ & $\begin{array}{c}\text { After } \\
\text { EB }\end{array}$ & $\begin{array}{c}\text { After EB } \\
\text { with wet scrubber }\end{array}$ \\
\hline 2.184 & 2,2-Dimethoxypropane, $\mathrm{C}_{5} \mathrm{H}_{12} \mathrm{O}_{2},\left(\mathrm{CH}_{3} \mathrm{O}\right)_{2}-\mathrm{C}-\left(\mathrm{CH}_{3}\right)_{2}$ & + & - & - \\
3.817 & Toluene, $\mathrm{C}_{7} \mathrm{H}_{8}$ & + & + & + \\
27.001 & Methyl octanoate, $\mathrm{C}_{7} \mathrm{H}_{15} \mathrm{COOCH}$ & + & - & - \\
31.208 & Octanoic acid, $\mathrm{C}_{7} \mathrm{H}_{15} \mathrm{COOH}$ & + & + & - \\
\hline
\end{tabular}

Fig. 4a and Table 1, it is seen that the identified organic compounds from ship emission include: nitro compounds (nitropropanone, 3-nitro-1-butene), esters (methyl butyrate, butoxyethoxyethyl acetate, (hexadecanoic acid, methyl ester), dibutyl phthalate, (octadecanoic acid, methyl ester), aliphatic hydrocarbons $\left(\mathrm{C}_{\mathrm{x}} \mathrm{H}_{2 \mathrm{x}+2}, \mathrm{x}=12,15-18,20-21\right)$, toluene and chlorotoluene. Most organic compounds are removed from flue gas after the application of the EB treatment (see Fig. 4b). Chlorotoluene and nitro compounds are removed completely from gas phase; however, some aliphatic compounds (dodecane, hexadecane and octadecane) with high concentration (Table 3) still exist in the gas phase; butoxyethoxyethyl acetate and dibutyl phthalate were still detected by the GC-MS analyser. After the application of EB and wet scrubber treatment (see Fig. 4c), only toluene, hexadecane, octadecane and dibutyl phthalate were present in the gas phase, while other organic compounds are completely removed.

\section{VOCs collected in the XAD-2 sorbent}

To capture other organic pollutants which were not effectively adsorbed from flue gas by CSC sorbents, XAD-2 sorbent was connected after the CSC sorbents. Analytical results of the GC-MS were presented in Fig. 5 and Table 2. It is seen that 2,2-dimethoxypropane, methyl octanoate, octanoic acid and toluene were detected in the flue gas emitted from ship (see Fig. 5a and Table 2). After
EB treatment (Fig. 5b), 2,2-dimethoxypropane $(\mathrm{RT}=2.184 \mathrm{~min})$ and methyl octanoate $(\mathrm{RT}=$ 31.208) were removed from flue gas. Then, after EB
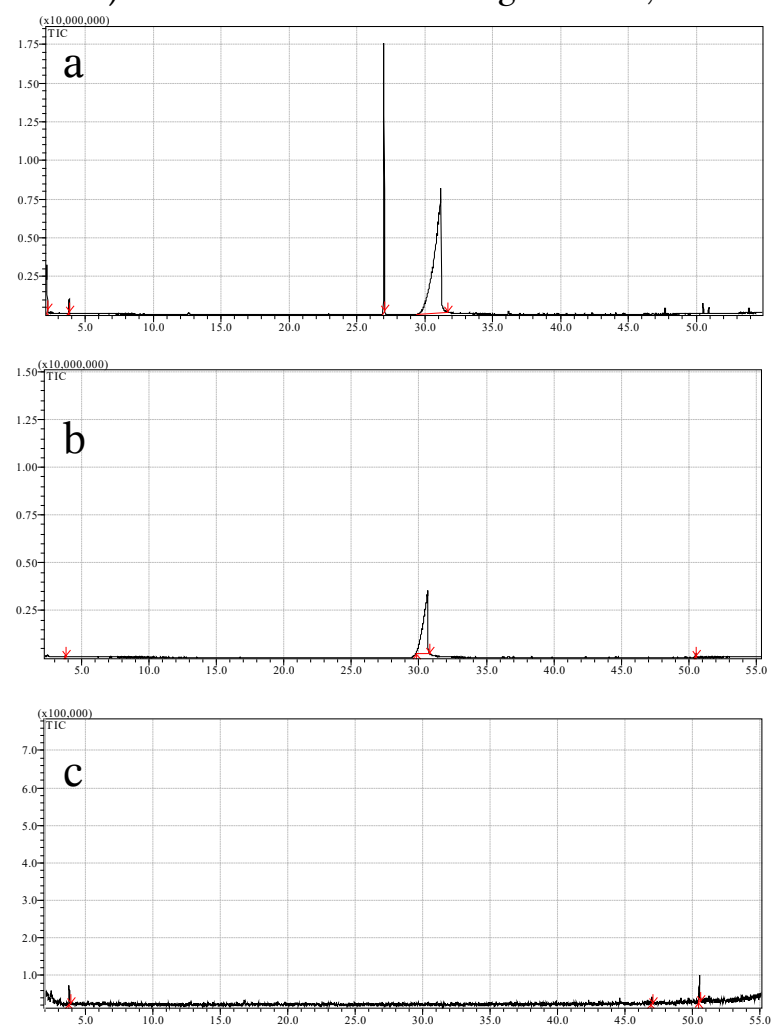

Fig. 5. (a) A GC-MS spectrum of flue gas collected with the XAD-2 sorbents (a) before EB irradiation; (b) after EB irradiation; (c) after EB with wet scrubber treatment. 


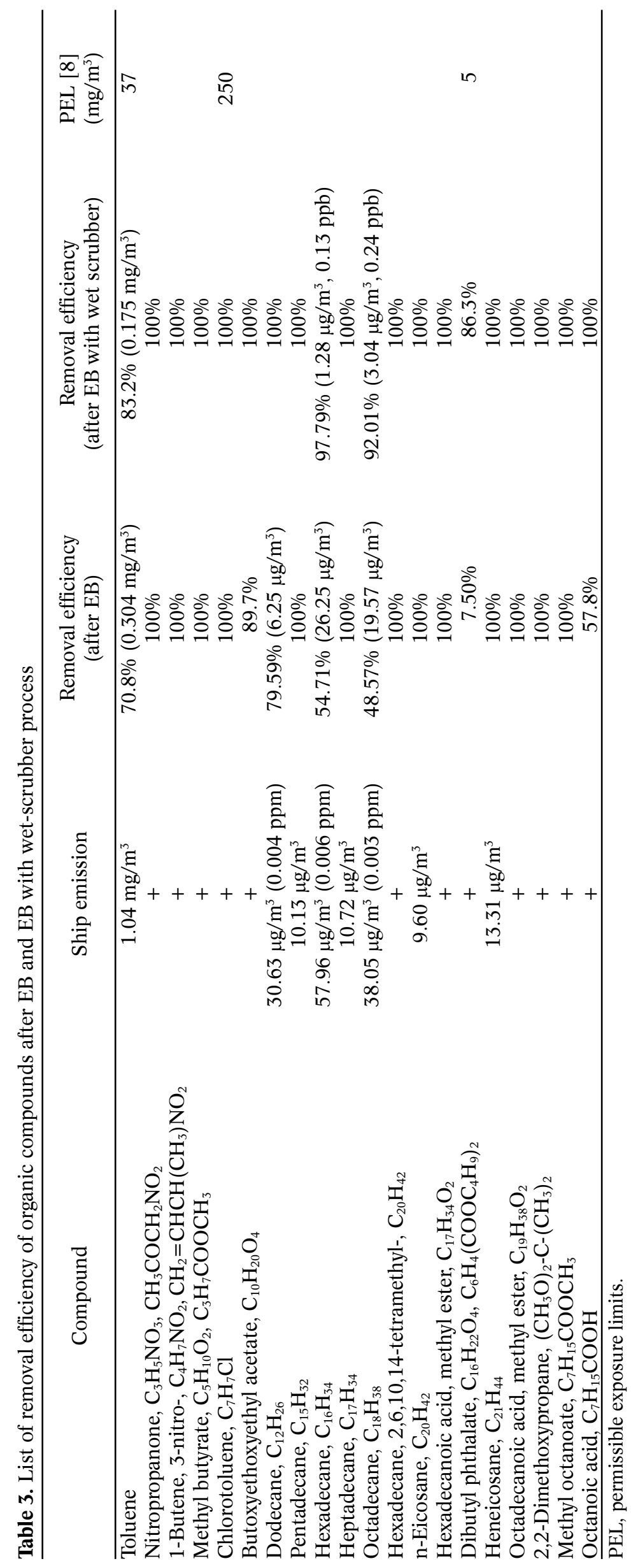


with wet scrubber treatment, only toluene $(\mathrm{RT}=$ $3.817 \mathrm{~min}$ ) was present in the flue gas.

\section{Removal efficiency of organic compounds}

We summarized the analytical results obtained from CSC and XAD-2 sorbents, and the removal efficiency of the organic pollutants after EB and EB with wet scrubber process are presented and listed in Table 3. For these organic compounds which we had standard solutions for making calibration curve, their concentrations are given in Table 3 . For other organic compounds, only removal efficiency was given based on their area counting given by the GC spectrum. It is seen that the toluene concentration was relatively high, around $1.04 \mathrm{mg} / \mathrm{m}^{3}$ in the flue gas arising from ship emission. Concentration of aliphatic hydrocarbons varies from $9.60 \mu \mathrm{g} / \mathrm{m}^{3}$ (n-eicosane) to $57.96 \mu \mathrm{g} / \mathrm{m}^{3}$ (hexadecane). After EB treatment, most VOCs were removed from gas phase. When degradation efficiency for aliphatic hydrocarbons is considered, the compounds with lower carbon chain have higher removal efficiency, namely $79.59 \%$ for dodecane and $48.57 \%$ for octadecane. Removal efficiencies of butoxyethoxyethyl and octanoic acid were $89.7 \%$ and $57.8 \%$, respectively. However, only $7.5 \%$ dibutyl phthalate was removed from flue gas after EB treatment. Eicosane and heneicosane were not detected after EB treatment due to their very low concentration in the flue gas. For those compounds with relatively high concentration, (e.g., toluene, hexadecane, octadecane and dibutyl phthalate) their removal efficiency greatly increased after EB with wet-scrubbing process, when compared to EB treatment alone, from $70.8 \%$ to $83.2 \%$ for toluene, $54.71 \%$ to $97.79 \%$ for hexadecane, $48.57 \%$ to $92.01 \%$ for octadecane and from $7.50 \%$ to $86.3 \%$ for dibutyl phthalate. Toluene concentration in flue gas emitted from ships decreased from $1.04 \mathrm{mg} / \mathrm{m}^{3}$ to $0.175 \mathrm{mg} / \mathrm{m}^{3}$ after EB with wet-scrubbing process.

\section{Conclusions}

Pilot test in Riga shipyard shows that most organic pollutants are removed from flue gas after $4.2 \mathrm{kGy}$ EB irradiation. Chlorotoluene and nitro compounds are removed completely from gas phase and some aliphatic compounds (dodecane, hexadecane and octadecane) with high concentration still exist in the gas phase; their removal efficiency varies from $79.59 \%$ for dodecane and $48.57 \%$ for octadecane. After EB and wet scrubber treatment, most organic pollutants are removed completely from flue gas, and only traces of toluene $\left(0.175 \mathrm{mg} / \mathrm{m}^{3}\right)$, hexadecane $(0.13 \mathrm{ppb})$, octadecane $(0.24 \mathrm{ppb})$ and dibutyl phthalate were present in the gas phase. Their removal efficiency might be further increased by increasing irradiation dose, increasing liquid/ gas ratio and residence time of flue gas in the wetscrubber and increasing temperature of the scrubber solution. Successful ARIES proof-of-concept tests in Riga Shipyard have demonstrated results that created an opportunity for the further on board tests and application of the technology on board of the sea-going ships on regular routes within the HERTIS (Hybrid Exhaust-gas-cleaning Retrofit Technology for International Shipping) Collaboration.

Acknowledgments. This work was partly financed by European ARIES project - Accelerator Research and Innovation for European Science and Society (H2020 GA no. 730871) (A. G. Chmielewski, T. Torims, G. Mattausch), co-financed by Polish Ministry of Science and Higher Education grant no. 3697/H2020/2017/2 (A. G. Chmielewski, Y. Sun, A. Pawelec) and by Polish Ministry of Science and Higher Education (INCT statutory task 4.3) (Y. Sun, A. Pawelec).

\section{ORCID}

A. G. Chmielewski (D) http://orcid.org/0000-0001-6262-5952 Y. Sun (D) http://orcid.org/0000-0002-7359-3869

\section{References}

1. US Environmental Protection Agency. (2020). Initial list of hazardous air pollutants with modifications. Retrieved September 30, 2020, from https://www.epa. gov/haps/initial-list-hazardous-air-pollutants-modifications.

2. US Environmental Protection Agency. (2020). MARPOL Annex VI and the Act to Prevent Pollution from Ships (APPS). Retrieved September 30, 2020, from https://www.epa.gov/enforcement/marpol-annex-vi-and-act-prevent-pollution-ships-apps.

3. Sun, Y., Zwolińska, E., \& Chmielewski, A. G. (2016). Abatement technologies for high concentrations of $\mathrm{NOx}$ and $\mathrm{SO}_{2}$ removal from exhaust gases: A review. Crit. Rev. Environ. Sci. Technol., 46(2), 119-142. http://dx.doi.org/10.1080/10643389.2015.1063334.

4. Zwolińska, E., Sun, Y., Chmielewski, A. G., Pawelec, A. \& Bułka, S. (2020). Removal of high concentrations of NOx and SO2 from diesel off-gases using a hybrid electron beam technology. Energy Rep., 6, 952-964. https://doi.org/10.1016/j.egyr.2020.04.008.

5. Torims, T., Kravalis, K., Pikurs, G., Ruse, A., Chmielewski, A. G., Pawelec, A., Zimek, Z., Mattausch, G., \& Vretenar, M. (2020). Development of a hybrid electron accelerator system for the treatment of marine diesel exhaust gases. In Proceedings of the 11th International Particle Accelerator Conference, May 10-15, 2020, Ganil/Caen, France. DOI: 10.18429/JACoW-IPAC2020-THVIR14.

6. US Environmental Protection Agency. (2019). Method 18 - Measurement of gaseous organic compound emissions by gas chromatography. Retrieved September 30, 2020, from https://www.epa.gov/sites/production/files/2019-06/documents/method_18_0.pdf.

7. Basfar, A. A., Fageeha, O. I., Kunnummāl, N., Al-Ghamdi, S., Chmielewski, A. G., Licki, J., Pawelec, A., Tymiński, B., \& Zimek, Z. (2008). Electron beam flue gas treatment (EBFGT) technology for simultaneous removal of $\mathrm{SO}_{2}$ and $\mathrm{NOx}$ from combustion 
of liquid fuels. Fuel, 87, 1446-1452. https://doi. org/10.1016/j.fuel.2007.09.005.

8. US Department of Labor. (2020). Occupational safety and health standards. Toxic and hazardous substances. TABLE Z-1 - Limits for air contaminants. Retrieved September 30, 2020, from https:// www.osha.gov/laws-regs/regulations/standardnumber/1910/1910.1000TABLEZ1. 